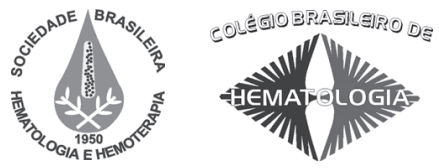

\title{
Brazilian experience using high-dose sequential therapy (HDS) followed by autologous hematopoietic stem cell transplantation (ASCT) for malignant lymphomas
}

\author{
Experiência brasileira utilizando terapia sequencial de alta dose seguido de transplante autólogo \\ de célula-tronco hematopoética para linfomas malignos
}

\author{
Cármino A. de Souzal \\ Kátia B. B. Pagnano ${ }^{2}$ \\ Irene Lorand-Metze ${ }^{3}$ \\ Eliana C. M. Miranda ${ }^{4}$ \\ Renata Baldissera ${ }^{5}$ \\ Francisco J. P. Aranha ${ }^{6}$ \\ Afonso C. Vigorito ${ }^{7}$ \\ Bruno K. L. Duarte ${ }^{8}$
}

\begin{abstract}
Using the overall survival (OS), disease free survival (DFS) and progression free survival (PFS), as well as associated toxicity, the purpose of this work was to evaluate the effectiveness of HDS followed by ASCT as salvage therapy. A retrospective analysis was performed of 106 patients with high grade non-Hodgkin lymphoma receiving HDS followed by ASCT, between 1998 and 2006. Median age was 45 years (Range: 8-65), with 66 (62\%) men. Histopathological classification was: $78 \%$ DLBCL patients, $12 \% \mathrm{~T}$ and anaplastic and $9 \%$ Mantle cell lymphomas; $87 \%$ had B cell and $12 \% \mathrm{~T}$ cell lymphomas; 83\% were stage III-IV (Ann Arbor Staging), 63\% had B symptoms, $32 \%$ had bone marrow involvement, $62 \%$ bulky disease and $42 \%$ high-intermediate or high risk IPI. After HDCY, 9 patients died, 7 from toxicity and 2 from sepsis. Eighty patients underwent ASCT, 47\% were in complete remission (CR) and 15\% died, all from toxicity. Their OS was 45\% over 8 years. During the follow-up, another 35 patients died [4 CR, 1 partial response (PR), 2 relapsed disease $(R D)$ and 28 disease progression (DP)], 11 (31\%) had not performed ASCT. OS was 37\%; DFS was $49 \%$ and PFS 28\%. OS by diagnosis was $42 \%$ for DLBCL, $40 \%$ for T-cell (8 y) and $20 \%$ for Mantle Cell (6y) ( $P=N S)$. OS by B symptom patients was $22 \%$ vs. $58 \%(P=0.002)$ and PFS was $23 \%$ vs. $37 \%(P=0.03)$. Patients who achieved CR after HDCY (38) had significantly better OS and PFS (38\% and 17\%) than patients who remained in $D P(P<0.0001)$. Cox Regression demonstrated therapeutic lines before HDCY (Relative risk $-R R=1.41 ; C I 95 \%: 1.04-1.90 ; P=0.02)$ and $P D$ both before $(R R=$ 2.70; CI 95\%: 1.49-4.91, $P<0.001)$ and after $\operatorname{HDCY}(R R=5.38 ; 95 \%$ CI: 2.93-9.87; $P<0.0001)$. Conclusions: Our study suggests HDS is an efficient treatment to improve status and to reduce tumoral burden. Regardless of toxicity-related mortality it is feasible, especially considering the poor prognosis of patients. Rev. Bras. Hematol. Hemoter. 2009;31(Supl. 2):9-14.
\end{abstract}

Key words: High dose sequential therapy; autologous hematopoietic stem cell transplantation; non-Hodgkin lymphoma; Brazilian experience

\footnotetext{
${ }^{l}$ Médico Hematologista - Coordenador do Centro de Hematologia e Hemoterapia da Unicamp - Campinas-SP.

${ }_{3}^{2}$ Médica Hematologista - Médica contratada do Centro de Hematologia e Hemoterapia da Unicamp - Campinas-SP.

${ }^{3}$ Médica Hematologista - Coordenadora-Associada do Centro de Hematologia e Hemoterapia da Unicamp - Campinas-SP.

${ }_{5}^{4}$ Data Manager - M.Ed (mestre) Doutoranda em Clínica Médica.

Médica Hematologista - Chefe da Disciplina de Hematologia Faculdade de Medicina de Marilia (Famema) - Marilia-SP.

${ }^{6}$ Médico Hematologista - Supervisor do Ambulatório de Quimioterapia do Centro de Hematologia e Hemoterapia da Unicamp - Campinas-SP.

Médico Hematologista - Supervisor da Unidade de TMO / Centro de Hematologia e Hemoterapia da Unicamp - Campinas-SP.

${ }^{8}$ Resídente Clínica Médica - Departamento Clínica Médica / Faculdade de Ciências Médicas / Unicamp - Campinas-SP.
}

Universidade Estadual de Campinas - Unicamp - Campinas-SP.

Correspondence: Cármino Antonio de Souza

Rua Carlos Chagas, 480 - Hemocentro - Barão Geraldo

13083-970 - Campinas-SP

E-mail: carmino@unicamp.br 


\section{Introduction}

A dose intensified regimen, such as high dose sequential therapy (HDS) followed by autologous hematopoietic stem cell transplantation (ASCT) is an effective and feasible salvage therapy for resistant and relapsed malignant lymphomas. ${ }^{1,2,3-8}$ It consists of an intensified debulking phase by sequential administration of high-dose cyclophosphamide (HDCY) followed by high-dose methotrexate (HDMTX), (only for Hodgkin's lymphoma - HL) and high-dose etoposide (HDVP), peripheral blood progenitor cell (PBPC) harvesting, HDS and ASCT. ${ }^{9}$

Despite proof of its efficacy reported by several investigators for both $\mathrm{HL}^{10-12}$ and non-Hodgkin's lymphoma (NHL), ${ }^{13-15}$ there are few studies using this strategy in Brazil and few groups around the world evaluated the use of this therapy with over 5-year follow-up periods. Our aim was to evaluate the effectiveness and toxicity of HDS used as salvage therapy for malignant lymphomas, focusing on overall survival (OS), disease free survival (DFS) and progression-free survival (PFS).

\section{Patients and Method}

Seventy-seven patients diagnosed with relapsed or refractory HL and 106 patients with high grade NHL were treated with HDS between 1998 and 2006 in three different institutions: University of Campinas, Vera Cruz Hospital and the Boldrini Children's Cancer Center. Data was obtained from the patients' medical records. Eligibility criteria included failure to achieve complete remission (CR) after first-line treatment (nonresponsive, NR), relapsed disease even when in CR before mobilization, and adequate psychiatric conditions to participate. All patients or their legal representatives provided written, informed consent before receiving this regimen. Treatment procedures were approved by the Research Ethics Committee of each participating institution, according to the principles of the Helsinki Declaration.

\section{Treatment procedures and definitions}

HDS consisted of the sequential administration of HDCY ( 4 or $7 \mathrm{~g} / \mathrm{m}^{2}$ ) and G-CSF ( $300 \mu \mathrm{g} /$ day, from day +1 after HDCY), followed by PBPC harvesting when white blood cells increased to $>1.0 \times 10^{9} / \mathrm{L}$, with the aim of collecting $>5 \times 10^{6} \mathrm{CD} 34+$ cells/ $\mathrm{kg}$. G-CSF was stopped after the last day of apheresis. Patients with an insufficient number of CD34+ cells underwent another collection after etoposide. In some cases where peripheral cells could not be harvested, harvesting was made directly from the bone marrow. After PBPC harvesting, methotrexate $\left(8 \mathrm{~g} / \mathrm{m}^{2}\right)$ plus vincristine $\left(1.4 \mathrm{mg} / \mathrm{m}^{2}\right)$ (only in patients with $\mathrm{HL}$ ) and etoposide $\left(2 \mathrm{~g} / \mathrm{m}^{2}\right)$ were administered.

Disease status was assessed preferably before HDCY, before ASCT, after ASCT and throughout the long-term follow- up (every three months in the first year, every six months in the second year and annually thereafter).

\section{Data collection and statistical analysis}

Analysis was based on data available in February 2009. OS was calculated from HDCY date until the date of death or last follow-up. DFS included only patients who achieved CR and was calculated from the date of CR assessment until the date of relapse, last follow-up or death. PFS included all patients and was calculated from HDCY date until the date of progression, relapse, last follow-up or death due to any cause. Actuarial curves of OS, DFS and PFS were analyzed using the Kaplan-Meier method and compared by the log-rank test. Multivariate predictors of outcome (OS, DFS and PFS) were assessed by Cox regression analysis, using the forward stepwise Wald test $(\mathrm{P}<0.05)$.

\section{Results}

\section{Hodgkin's Lymphoma}

\section{Patients' characteristics}

The median age was 23 years (Range: $7-68$ ) at diagnosis, with 46/77 (60\%) men. Histopathological diagnosis ${ }^{16}$ was: $65 \%$ nodular sclerosis, $25 \%$ mixed cellularity, $6 \%$ lymphocyte depleted, $1.5 \%$ lymphocyte predominant and $2.5 \%$ patients unknown. Stage III-IV ${ }^{17}$ was $65 \%, 71 \%$ had B symptoms, 14\% had bone marrow involvement and $40 \%$ had bulky disease $(\geq 10 \mathrm{~cm})$. Before HDCY, patients were treated with a median of two therapeutic lines, including conventional chemotherapy and radiotherapy. Three patients were in CR after treatment with conventional therapy for relapsed disease and $54.5 \%$ were in disease progression (DP) before mobilization with HDCY.

Mobilization, PBPC harvesting and toxicity

CY was administered after a median time of 1.5 years from diagnosis. Thirty patients (39\%) received a dose of $4 \mathrm{~g} / \mathrm{m}^{2}$ due to advanced age ( $>65$ years) or borderline cardiac function, and 47 patients $(61 \%)$ received $7 \mathrm{~g} / \mathrm{m}^{2}$. The latter group had more patients in DP (57\% vs. 50\%; $p=0.02)$ and more patients with B symptoms ( $80 \%$ vs. $57 \% ; p=0.02)$. The $4 \mathrm{~g} / \mathrm{m}^{2}$ group had a greater prevalence of previous use of radiotherapy $(73 \%$ vs. $44 \% ; p=0.01)$. There were no significant differences in the other parameters.

The median day of leukapheresis after HDCY was +13 (Range: 8-27), with a median of three sessions (Range: 1-8) and a median number of harvested CD34+ cells of $5.98 \times 10^{6}$ cells/kg (Range: $\left.0.23-45.01 \times 10^{6}\right)$.

Twenty-one patients (27\%) died after HDCY. Six died from toxicity, nine from DP, four from sepsis while in DP and insufficient cells were harvested from one; this patient developed myelodisplastic syndrome (MDS) and died from 
sepsis while in CR. Moreover, one case died 16 months after HDS from refractory congestive heart failure, giving a total of $7 /$ $77(9 \%)$ patients with HDS-related mortality. Besides these patients, three more were not submitted to ASCT, thus 24 patients (31\%) did not undergo ASCT.

We obtained data on toxicity for 71 patients. Sixty-six patients $(93 \%)$ presented with hematologic toxicity. Forty patients experienced gastrointestinal toxicity, nine patients from cardiac toxicity, six patients from asymptomatic reduction of the ejection fraction, one patient from cardiac failure and another one died with severe heart failure. Seven patients developed acute renal failure not related to sepsis. Finally, 19 patients had fever of unknown origin.

\section{Autografting}

Autografting was performed in 53 patients with a median of 118 days after HDCY (Range: 62-407). BEAM was used as a conditioning regimen in $81 \%$. The median times for granulocyte $\left(>0.5 \times 10^{9} / \mathrm{L}\right)$ and platelet $\left(>20 \times 10^{9} / \mathrm{L}\right)$ engraftment were 11 days (Range: 9-27) and 17 days (Range: 6-88), respectively. Autoengraftment related mortality was $6 \%$. OS for transplanted patients was $46 \%$ over five years. Twenty-nine patients died after ASCT as described in the long-term outcome.

\section{Long-term outcome}

Of the 77 patients who were submitted to HDCY, 21 died before ASCT. Another three patients did not undergo ASCT. A total of 53 patients were submitted to ASCT and until now $45 \%$ are alive. Twenty-nine patients died after ASCT. Another patient developed MDS and is alive, totaling four patients (5\%) who developed AML/MDS.

A total of 27 patients are alive for a median of 66 months after HDCY (Range: 3-128). Eighteen patients are in CR for a median of 70 months after HDCY (Range: 17-128).

OS was $27 \%$ with a median time of 18 months (Range: 0.1 128 ); DFS was $57 \%$ with a median of 45 months (Range: $1.5-125$ ); PFS was $25 \%$ with a median 13 months (Range: $0.1-128$ ).

We analyzed the survival of patients initially in DP (57/77 - 74\%) according to their disease status before HDCY. Patients who achieved CR after HDCY (24/57 - 42\%) had a significantly better OS and PFS (36\%-33\%) than patients who remained in DP $(10 \%-17 \%)$. We also analyzed the survival of patients according to HDCY dose, for which no significant difference was found.

Additionally we analyzed survival data based on age, stage and histopathological and laboratory findings at diagnosis and found no significant differences.

For the multivariate analysis two variables remained: $\mathrm{LDH}$ (as categorical variable - Hazard ratio - HR $=2.41 ; 95 \%$ CI: $1.04-$ $5.59 ; \mathrm{P}=0.04)$ and DP after HDCY $(\mathrm{HR}=3.97 ; 95 \% \mathrm{CI}: 1.73-9.10$; $\mathrm{P}=0.001$ ). In summary, $65 \%$ patients died; $46 \%$ from $\mathrm{DP}, 26 \%$ from sepsis, $14 \%$ had HDS-related deaths, $6 \%$ had ASCT-related deaths, $6 \%$ had AML/MDS and $2 \%$ had extensive chronic graftverses-host disease (GVHD) due to a reduced intensity conditioning (RIC) allogeneic transplantation.

\section{Non-Hodgkin Lymphoma}

\section{Patients' characteristics}

One hundred and six patients were enrolled with a median age of 45 years (Range: 8-65), with 66 men. Histopathological classification ${ }^{16}$ was: $78 \%$ diffuse large Bcell lymphoma (DLBCL), 12\% $\mathrm{T}$ and anaplastic lymphoma and $10 \%$ mantle cell lymphoma. At diagnosis, $83 \%$ were in stage III-IV, ${ }^{17} 63 \%$ had B symptoms, $32 \%$ had bone marrow involvement, $62 \%$ bulky disease and $42 \%$ had highintermediate or high risk IPI 18.

Before HDCY, patients were treated with a median of one therapeutic line, including conventional chemotherapy and radiotherapy. Six patients were in CR after their first relapse after treatment with conventional chemotherapy and 38 were in partial response (PR). More than half were in DP or refractory relapsed disease.

\section{Mobilization, PBPC harvesting and toxicity}

$\mathrm{CY}$ was administered after a median time of 10 months after diagnosis. Forty-two patients received a dose of $4 \mathrm{~g} /$ $\mathrm{m}^{2}$ and 64 patients received $7 \mathrm{~g} / \mathrm{m}^{2}$. Groups differed statistically according to IPI $\left(66 \%-4 \mathrm{~g} / \mathrm{m}^{2}\right.$ vs. $30 \%-7 \mathrm{~g} / \mathrm{m}^{2}$; $p=0.006)$ and in prevalence of altered serum LDH $(68 \%$ $4 \mathrm{~g} / \mathrm{m}^{2}$ vs. $\left.41 \%-7 \mathrm{~g} / \mathrm{m}^{2} ; p<0.0001\right)$.

The median leukapheresis day after the HDCY was +13 (Range: 3-83), with a median of two sessions (Range: 17 ) and a median number of harvested CD34+ cells of $6.74 x$ $10^{6}$ cells $/ \mathrm{kg}$ (Range: $\left.1.29-44.01 \times 10^{6}\right)$.

Eighteen patients (17\%) died after HDCY. As well as these patients, 8 did not undergo ASCT, totaling 26 patients $(24.5 \%)$ who were not submitted to ASCT.

We were able to recover toxicity data for $102(96 \%)$ patients. All patients presented hematologic toxicity. Fortyseven patients experienced gastrointestinal toxicity, ten cardiac toxicity, six asymptomatic reduction of the ejection fraction, two heart failures, one severe pleural effusion and one died due to severe congestive heart failure. Four patients presented acute renal failure that was not due to sepsis. Finally, $27(25.5 \%)$ patients presented fever of unknown origin.

\section{Autografting}

ASCT was performed in 80 patients after a median of 123 days (Range: $45-1710$ ) from HDCY. BEAM was used as a conditioning regimen in 87 . The median time for granulocyte engraftment (neutrophil count $>0.5 \times 10^{9} / \mathrm{L}$ ) was 11 days (Range: 6-29) and 16 days (Range: 5-70) for platelet engraftment (platelet count $>20 \times 10^{9} / \mathrm{L}$ ). Auto-engraftment related to mortality was $14 \%$. Twenty-six patients did not autograft.

Only five patients who were not submitted to ASCT are alive: $1 \mathrm{DP}, 2 \mathrm{CR}$ and $2 \mathrm{PR}$. OS for patients submitted to ASCT was $45 \%$ over eight years. 


\section{Long-term outcome}

Twenty-six patients did not undergo ASCT: 18 died prior to the procedure and eight patients were not transplanted for other reasons, with six of them still alive. Another 37 patients died during follow-up, 11 due to ASCT toxicity, 12 due to DP, 13 from sepsis and one from chronic GVHD after being submitted to a RIC allogeneic transplantation. One patient developed MDS and remains alive.

Until the closing date of this analysis, 49/106 patients are alive, with a median of 68 months. OS was $41 \%$ with a median of 30 months (Range: $0.2-124$ ), DFS was $49 \%$ with a median of 36 months (Range: $1.5-118$ ) and PFS was $31 \%$ with a median of 16 months (Range: $0.2-124$ ).

We observed better OS (60 and 40\%) and PFS (27 and $24 \%)$ for patients without B symptoms at diagnosis $(p=0.03$ and $p=0.02$, respectively). Patients who achieved CR after HDCY (38) had significantly better OS and PFS (44\%-27\%) compared to patients who remained in DP (24 patients with $0 \%$ and $0 \%$ )

OS, PFS and DFS were not affected by the CY dose. We also analyzed the outcome of patients based on age, stage, histopathological findings at diagnosis and IPI and found no significant differences.

From the variables included in univariate analysis, DP before $(\mathrm{HR}=2.56$; CI 95\%: 1.42-4.62; $p<0.001)$ and after $(\mathrm{HR}$ $=5.52 ;$ CI 95\%: 3.01-10.1; $<<0.001)$ HDCY were associated with worse OS.

On multivariate analysis, the results were: presence of B symptoms, LDH, and DP or relapse before HDCY for OS, whereas for PFS, B symptoms and DP or relapse before HDCY remained.

Overall, mortality was 57/106 (54\%); causes were 42\% DP, $12 \%$ related to HDCY, $19 \%$ related to ASCT, $23 \%$ infections, $2 \%$ from chronic GVHD after being submitted to a RIC allogeneic transplantation and $2 \%$ from an unknown cause. In addition, one patient developed MDS and remains alive.

\section{Discussion}

The intention of analyzing a Brazilian cohort has several implications because the frequency of some important poor prognostic factors, such as B symptoms and bulky disease, are higher in our patients compared to series from the Northern Hemisphere. ${ }^{19-21}$ In an Italian study ${ }^{22}$ evaluating HDS in 102 patients with refractory or recurrent HL, $42 \%$ had B symptoms and $29 \%$ had bulky disease. In another study ${ }^{23}$ evaluating the use of HDS and ASCT in 494 Spanish patients with refractory or recurrent HL, $40.5 \%$ had B symptoms and 33\% had bulky disease. These numbers contrast with the $71 \%$ of patients with B symptoms and the $40 \%$ of patients with bulky disease seen in our patients with HL. The same is true with NHL patients.

The higher prevalence of such variables in our population indicates that they are probably expected to have poorer results when compared to other populations in developed countries.

Another possible factor contributing to a worse outcome in our patients is a high prevalence of Epstein-Barr virus-associated (EBV-associated) HL, although we did not collect this information. Despite the controversy surrounding the possible influence of EBV on the outcome of HL, a few studies suggest that OS is worse when EBV is present in adult patients. ${ }^{24}$ While the prevalence of EBV in developed countries is around $30 \%,{ }^{24}$ one study performed at our institution showed a prevalence of $64 \% .{ }^{20}$ This difference may be due to low socioeconomic status (as we are a governmental institution which provides care for low income patients) and not due to ethnic differences between our population and those from developed countries. A lower income leads to a delay in diagnosis.

The higher prevalence of worse prognostic factors in our population is reflected by the poor OS and PFS of HL patients $(27 \%$ and $25 \%)$ when compared to other studies, with OS and PFS ranging from 50\%-65\%. ${ }^{22,25-27}$ However, this was not observed for NHL patients, with OS of $41 \%$ and a PFS of $31 \%$, similar to those observed by other authors, where OS ranged from $40 \%-45 \% .^{13-15,27,28}$

This difference in response between HL and NHL patients has not been previously reported. Although the greater prevalence of high-risk patients can justify the worse survival observed in our HL patients, it should have also impacted survival of NHL patients. This finding, in a population of similar social-demographic conditions, with high-risk, advanced disease treated under the same protocol and within the same institution shows the need of a better understanding of the differences between the response of HL and NHL to HDS.

These data should point to a review of HDCY use in HL, usually a more benign disease, where patients could benefit from less intensive regimens. The lower number of studies evaluating HDS in HL than in NHL only reinforces the need for such a review.

However, the use of different doses, and sometimes drugs, between our study and others should be highlighted as a factor which could justify the differences mentioned above.

We did not expect the lack of benefit of using a higher dose regimen in both HL and NHL. We employed at our institution a $7 \mathrm{~g} / \mathrm{m}^{2}$ dose of HDCY and a less intense one of $4 \mathrm{~g} / \mathrm{m}^{2}$ based on findings of the Italian group. ${ }^{28}$ This was developed based on the Norton-Simon hypothesis ${ }^{29}$ that we should seek a treatment regimen that employs the highest possible dosing, over the minimum period of time, with acceptable toxicity. By showing no extra benefit, neither in OS nor in response rates, of the higher dose regimen, our study suggests that its benefit was exceeded by its toxicity, resulting in a similar survival rate, when compared to a less dose-intense regimen. 
Even though the $7 \mathrm{~g} / \mathrm{m}^{2}$ regimen did not improve survival, the role of a high-dose debulking regimen is highlighted by the observation that patients previously in DP, who responded to HDCY and achieved CR, had a better overall survival. This not only shows the ability of HDCY to overcome primary chemo-resistance in a significant proportion of refractory patients, but also its importance in assessing malignant lymphoma chemo-sensitivity, since there was no benefit in submitting patients to HDS and ASCT when they did not respond to HDCY.

Nevertheless, this high-dose debulking regimen imposed a high toxicity burden, with HDCY-related mortality of $6.6 \%$ for NHL and $7.8 \%$ for HL, which is slightly worse than the $5 \%$ rate observed elsewhere, ${ }^{28}$ but still acceptable.

One point that should be noted is the incidence of secondary hematological malignancy, especially in HL patients. We know today that death due to second cancers is now the most common cause of mortality among long-term survivors of HL. ${ }^{30}$ The incidence of secondary hematological malignancy for HL in our study was 5.2\%. This rate appears to be similar to those observed in other studies, ${ }^{31,32}$ and although credited to the cytotoxic effects of alkylating agents, the role of cytogenetic instability related to the disease and ASCT has yet to be determined, especially when we consider the significantly lower incidence of this complication in patients with NHL in our study $(0.9 \%)$ treated under the same regimen.

Our study has some limitations typical of retrospective studies. However, we can conclude that despite the significant number of toxicity-related deaths, our data suggest that this regimen is feasible, especially for chemo-sensitive patients. The development of secondary neoplasias is a special concern in this setting, particularly for HL patients.

\section{Resumo}

A proposta deste trabalho foi avaliar a eficácia da HDS seguida do transplante autólogo como terapia de salvamento através da sobrevida global, livre de doença e livre de progressão bem como sua toxicidade. Realizou-se estudo retrospectivo com 106 pacientes com LNH de alto grau de malignidade entre 1998 e 2006. A mediana de idade foi 45 anos (8-65); 62\% homens; DLBCL, 78\%; $12 \%$, T e anaplásico e 9\%, linfoma da zona do manto; $87 \%$, células B; $83 \%$ estádios III-IV; $63 \%$ com sintomas B; $32 \% \mathrm{com}$ infiltração da medula óssea ao diagnóstico; $62 \%$ com grande massa e 42\% com IPI de alto risco ou intermediário. Após alta dose de ciclofosfamida (HDCY), nove pacientes faleceram. Oitenta pacientes realizaram o transplante, sendo que $47 \%$ estavam em $R C$ e $15 \%$ faleceram devido à toxicidade. A sobrevida global foi de $45 \%$ em oito anos para estes pacientes. Trinta e cinco pacientes não realizaram o transplante por causas diversas. Sobrevida global para todos os pacientes foi de 42\%, DLBCL, 40\%; T-cell, $40 \%$ e zona do manto, $20 \%(P=N S)$. Pacientes que obtiveram $R C$ após HDCY tiveram melhor sobrevida global e livre de progressão (38\% e 17\%, respectivamente) do que os que permaneceram em
$P D(P<0.0001)$. O modelo de Cox resultou que o número de linhas terapêuticas antes da HDCY (RR 1.41 IC 95\%: 1.04-1.90, P=0.02) e PD antes da HDCY (RR 2.70, IC 95\%: 1.49-4.91, $P<0.001) e$ após HDCY (RR 5.38, IC 95\%: 2.93-9.87, P<0.0001). Nosso estudo sugere que HDS é um método eficiente de tratamento para melhorar o status e reduzir a massa tumoral. Em relação à toxicidade, é factivel, especialmente em pacientes de prognóstico ruim Rev. Bras. Hematol. Hemoter. 2009;31(Supl. 2):9-14

Palavras-chave: Linfomas malignos; terapia sequencial de alta dose; transplante autólogo; experiência brasileira.

\section{Acknowledgments}

CCADS, BKLD and ECMM were the principal authors. They were primarily responsible for this paper from the conception until submission of the manuscript. The remaining authors qualified for authorship according to the World Association of Medical Editors (WAVE) and have taken specific responsibility for the following parts of content: ISV, ACV, FJPA, GBO, ILM, KBP, SRB and MN revised it critically for important intellectual content and collected, analyzed and interpreted the data. ECMM was also responsible for the statistical analyses. JFCMJ was responsible for aphaeresis procedures. All the authors have discussed and agreed with the final version of the paper. The authors thank Nicete Romano for secretarial assistance.

\section{References}

1. Verdonck LF, Dekker AW, de Gast GC, van Kempen ML, Lokhorst HM, Nieuwenhuis HK. Salvage therapy with ProMACE-MOPP followed by intensive chemoradiotherapy and autologous bone marrow transplantation for patients with non-Hodgkin's lymphoma who failed to respond to first-line CHOP. J Clin Oncol. 1992;10(12):1949-54.

2. Vose JM, Zhang MJ, Rowlings PA, Lazarus HM, Bolwell BJ, Freytes $\mathrm{CO}$, et al. Autologous transplantation for diffuse aggressive nonHodgkin's lymphoma in patients never achieving remission: a report from the Autologous Blood and Marrow Transplant Registry. J Clin Oncol. 2001;19(2):406-13.

3. Kewalramani T, Zelenetz AD, Hedrick EE, Donnelly GB, Hunte S, Priovolos AC, et al. High-dose chemoradiotherapy and autologous stem cell transplantation for patients with primary refractory aggressive non-Hodgkin lymphoma: an intention-to-treat analysis. Blood. 2000;96(7):2399-404.

4. Josting A, Reiser M, Rueffer U, Salzberger B, Diehl V, Engert A. Treatment of primary progressive Hodgkin's and aggressive nonHodgkin's lymphoma: is there a chance for cure? J Clin Oncol. 2000;18(2):332-9.

5. Santini G, Coser P, Congiu AM, Salvagno L, De Souza C, Sertoli MR, et al. VACOP-B, high-dose cyclophosphamide and high-dose therapy with peripheral blood progenitor cell rescue for aggressive non-Hodgkin's lymphoma with bone marrow involvement: a study by the non-Hodgkin's Lymphoma Co-operative Study Group. Haematologica. 2000;85(2):160-6.

6. Phillips GL, Wolff SN, Herzig RH, Lazarus HM, Fay JW, Lin HS, et al. Treatment of progressive Hodgkin's disease with intensive chemoradiotherapy and autologous bone marrow transplantation. Blood. 1989;73(8):2086-92.

7. Bierman PJ, Bagin RG, Jagannath S, Vose JM, Spitzer G, Kessinger A, et al. High dose chemotherapy followed by autologous 
hematopoietic rescue in Hodgkin's disease: long-term follow-up in 128 patients. Ann Oncol. 1993;4(9):767-73.

8. Moskowitz CH, Nimer SD, Zelenetz AD, Trippett T, Hedrick EE, Filippa DA, et al. A 2-step comprehensive high-dose chemoradiotherapy second-line program for relapsed and refractory Hodgkin disease: analysis by intent to treat and development of a prognostic model. Blood. 2001;97(3):616-23.

9. Gianni AM, Siena S, Bregni M, Lombardi F, Gandola L, Di Nicola $\mathrm{M}$, et al. High-dose sequential chemo-radiotherapy with peripheral blood progenitor cell support for relapsed or refractory Hodgkin's disease--a 6-year update. Ann Oncol. 1993;4(10):889-91.

10. Stella CC, Cazzola M, De Fabritiis P, De Vincentiis A, Gianni AM, Lanza F, et al. CD34-positive cells: biology and clinical relevance. Haematologica. 1995;80(4):367-87.

11. Tarella C, Caracciolo D, Corradini P, Zallio F, Ladetto M, Cuttica A, et al. Long-term follow-up of advanced-stage low-grade lymphoma patients treated upfront with high-dose sequential chemotherapy and autograft. Leukemia. 2000;14(4):740-7.

12. Vitolo U, Liberati AM, Lambertenghi Deliliers G, et al. A multicenter randomized trial by Italian Lymphoma Intergroup (ILI) comparing high dose chemotherapy (HDS) with autologous stem cell transplantation (ASCT) vs. intensified chemotherapy MegaCEOP in high risk diffuse large cell lymphoma (DLCL): no difference in outcome and toxicity. Blood 2001; 98: 725a.

13. Caracciolo D, Gavarotti P, Aglietta M, Bondesan P, Falda M, Gallo $\mathrm{E}$, et al. High-dose sequential (HDS) chemotherapy with blood and marrow cell autograft as salvage treatment in very poor prognosis, relapsed non-Hodgkin's lymphoma. Bone Marrow Transplant. 1993;12(6):621-5.

14. Cortelazzo S, Rambaldi A, Rossi A, Oldani E, Ghielmini M, Benedetti $\mathrm{F}$, et al. Intensification of salvage treatment with high-dose sequential chemotherapy improves the outcome of patients with refractory or relapsed aggressive non-Hodgkin's lymphoma. Br J Haematol. 2001;114(2):333-41.

15. Josting A, Sieniawski M, Glossmann JP, Staak O, Nogova L, Peters $\mathrm{N}$, et al. High-dose sequential chemotherapy followed by autologous stem cell transplantation in relapsed and refractory aggressive non-Hodgkin's lymphoma: results of a multicenter phase II study. Ann Oncol. 2005;16(8):1359-65.

16. Harris NL, Jaffe ES, Diebold J, Flandrin G, Muller-Hermelink HK, Vardiman J, et al. The World Health Organization classification of neoplasms of the hematopoietic and lymphoid tissues: report of the Clinical Advisory Committee meeting--Airlie House, Virginia, November, 1997. Hematol J. 2000;1(1):53-66.

17. Carbone PP, Kaplan HS, Musshoff K, Smithers DW, Tubiana M. Report of the Committee on Hodgkin's Disease Staging Classification. Cancer Res. 1971;31(11):1860-1.

18. A predictive model for aggressive non-Hodgkin's lymphoma. The International Non-Hodgkin's Lymphoma Prognostic Factors N Eng1 J Med. 1993;329(14):987-94.

19. de Souza CA, Vassallo J, Lorand-Metze I. Hodgkin's disease in Brazil: a clinicopathologic study. Haematologica. 1997;82(1):127-8.

20. Vassallo J, Metze K, Traina F, de Souza CA, Lorand-Metze I. Expression of Epstein-Barr virus in classical Hodgkin's lymphomas in Brazilian adult patients. Haematologica. 2001;86(11):1227-8.

21. Hallack Neto AE, Pereira J, Beitler B, Chamone DA, Llacer PD, Dulley FL, et al. Results of CHOP chemotherapy for diffuse large B-cell lymphoma. Braz J Med Biol Res. 2006 Oct;39(10):131522. Epub 2006 Aug 22.

22. Tarella C, Cuttica A, Vitolo U, Liberati M, Di Nicola M, Cortelazzo $\mathrm{S}$, et al. High-dose sequential chemotherapy and peripheral blood progenitor cell autografting in patients with refractory and/or recurrent Hodgkin lymphoma: a multicenter study of the intergruppo Italiano Linfomi showing prolonged disease free survival in patients treated at first recurrence. Cancer. 2003;97 (11):2748-59.

23. Sureda A, Arranz R, Iriondo A, Carreras E, Lahuerta JJ, GarcíaConde J, et al. Autologous stem-cell transplantation for Hodgkin's disease: results and prognostic factors in 494 patients from the Grupo Español de Linfomas/Transplante Autólogo de Médula Osea Spanish Cooperative Group. J Clin Oncol. 2001;19(5):1395-404.

24. Keegan TH, Glaser SL, Clarke CA, Gulley ML, Craig FE, Digiuseppe $\mathrm{JA}$, et al. Epstein-Barr virus as a marker of survival after Hodgkin's lymphoma: a population-based study. J Clin Oncol. 2005;23 (30): 7604-13.

25. Gianni AM, Siena S, Bregni M, Lombardi F, Gandola L, Valagussa P, et al. Prolonged disease-free survival after high-dose sequential chemo-radiotherapy and haemopoietic autologous transplantation in poor prognosis Hodgkin's disease. Ann Oncol. 1991;2(9): 645-53.

26. Josting A, Rudolph C, Mapara M, Glossmann JP, Sieniawski M, Sieber M, et al. Cologne high-dose sequential chemotherapy in relapsed and refractory Hodgkin lymphoma: results of a large multicenter study of the German Hodgkin Lymphoma Study Group (GHSG). Ann Oncol. 2005;16(1):116-23.

27. Baldissera RC, Aranha JF, Oliveira GB, Vigorito AC, Eid KA, Miranda EC, et al. High-dose cyclophosphamide followed by autologous peripheral blood progenitor cell transplantation improves the salvage treatment for persistent or sensitive relapsed malignant lymphoma. Braz J Med Biol Res. 2002;35(1):49-57.

28. Tarella C, Cuttica A, Caracciolo D, Zallio F, Ricca I, Bergui L, et al. High-dose sequential (HDS) chemotherapy for high-risk nonHodgkin's lymphoma: long-term analysis and future developments. Ann Hematol. 2001;80 Suppl 3:B123-6.

29. Norton L, Simon R. The Norton-Simon hypothesis revisited. Cancer Treat Rep. 1986;70(1):163-9.

30. Aleman BM, van den Belt-Dusebout AW, Klokman WJ, Van't Veer $\mathrm{MB}$, Bartelink H, van Leeuwen FE. Long-term cause-specific mortality of patients treated for Hodgkin's disease. J Clin Oncol. 2003;21(18):3431-9.

31. Lazarus HM, Loberiza FR Jr, Zhang MJ, Armitage JO, Ballen KK, Bashey A, et al. Autotransplants for Hodgkin's disease in first relapse or second remission: a report from the autologous blood and marrow transplant registry (ABMTR). Bone Marrow Transplant. 2001;27(4):387-96.

32. Wheeler C, Khurshid A, Ibrahim J, Elias A, Mauch P, Ault K, et al. Incidence of post transplant myelodysplasia/acute leukemia in non-Hodgkin's lymphoma patients compared with Hodgkin's disease patients undergoing autologous transplantation following cyclophosphamide, carmustine, and etoposide (CBV). Leuk Lymphoma. 2001;40(5-6):499-509.

Supported by Fapesp (Fundação de Amparo à Pesquisa do Estado de São Paulo).

O tema apresentado foi proposto pela Organização do $8^{\circ}$ Simpósio da Associação Ítalo-Brasileira de Hematologia, realizado durante o XIII Congresso de Transplante de Medula Óssea.

Publicado após concordância do editor.

Recebido: 22/06/2009

Aceito: $05 / 07 / 2009$ 